\title{
Research Article \\ Impact of integrated weed management practices on weed and morphological parameters of black gram (Phaseolus mungo)
}

\author{
J. P. Bholane, Kavita D. Rajput and V.M. Bhale
}

\begin{abstract}
SUMMARY
A field investigation was carried out during Kharif season in 2010 at Agronomy Department Farm, Dr. Panjabrao Deshmukh Krishi Vidyapeeth, Akola, to evaluate the effect of four herbicides (imazethapyr, pendimethalin, fenoxyprop-p-ethyl and quizalofop-p-ethyl) applied at different rates with different time of application (pre-emergence, post emergence and combination of both) and cultural practices i.e. hand weeding and hoeing on morphological and weed contributing parameters in black gram (Phaseolus mungo). Among all the weed control methods, pre-emergence application of pendimethalin@1.5 kg/ha showed superiority over weedy check and rest all other methods, which were under study and significantly increased plant height (44.37), number of functional leaves plant ${ }^{-1}(12.37)$, leaf area plant ${ }^{-1}(886.7)$, total dry matter weight plant ${ }^{-1}$ (18.77), leaf area index (2.96), number of root nodules plant ${ }^{-1}$ (27 at 45 DAS) (other at 60 DAS), when compared with weedy check.
\end{abstract}

Key Words : Weed parameters, Cultural methods, Herbicidal practices, WCE, WI, Morphological parameters

How to cite this article : Bholane, J.P., Rajput, Kavita D. and Bhale, V.M. (2021). Impact of integrated weed management practices on weed and morphological parameters of black gram (Phaseolus mungo). Internat. J. Plant Sci., 16 (AAEBSSD): 23-28, DOI: 10.15740/HAS/IJPS/16.AAEBSSD/23-28, Copyright@2021: Hind Agri-Horticultural Society.

Article chronicle : Received : 07.07.2021; Revised : 10.07.2021; Accepted : 15.07.2021

$\mathrm{B}$ lack gram (Phaseolus mungo) is one of the important pulse crop grown in the rainfed farming system throughout the India. It is the second most

\section{MEMBERS OF THE RESEARCH FORUM}

Author to be contacted :

J.P. Bholane, Dr. Panjabrao Deshmukh Krishi Vidyapeeth, Akola (M.S.) India

Email : jayubholane@gmail.com

Address of the Co-authors:

Kavita D. Rajput and V.M. Bhale, Dr. Panjabrao Deshmukh Krishi Vidyapeeth, Akola (M.S.) India important pulse crop covering 31,00,000 ha (16.28 \%) area in the country. It has high nutritive value and consist high content of proteins, vitamins and minerals. During Kharif (monsoon) season the weeds emerge along with the crop due to favourable environment condition and the crop suffers heavy loss from unchecked weeds particularly in the initial stage of its growth (Vats and Sawhney, 1981). In the later stage, however, the black gram offers good competition (Ali et al., 1982). Overall effect is that the weeds caused grain yield losses upto 
$50 \%$ or even more (Sharma and Nayital, 1991). The conventional method of weed control through cultural practices i.e. Hand weeding, Hoeing is not only too expensive but at times it is not feasible due to wet soil conditions prevailing during rainy season. So, the use of new selective herbicides (pendimethalin, fenoxyprop-pethyl, Imazethapyr and quizalofop-p-ehtyl) with cultural practices in legumes can be effective and economical for controlling the broad spectrum of annual grassy and broad leaf weeds (Yadav et al., 1983). Apart from growth and yield attributes, the nature of yield response to weed management determines the feasibility of adoption of the technology by growers. With these objectives, the present study was under taken to enhance morphological parameters of black gram by controlling annual and broad leaved weeds and reduced the crop weed competition through different chemical and cultural weed control practices.

\section{MATERIAL AND METHODS}

The experiment was conducted on the Research farm of Agronomy Department, Dr.Panjabrao Deshmukh Krishi Vidyapeeth (Dr.PDKV), Akola during Kharif season of 2010. The soil of the experimental field was clay loam with $\mathrm{pH} 7.8,0.55 \%$ organic carbon, 234.58 $\mathrm{kg} /$ ha available $\mathrm{N}, 20.86 \mathrm{~kg} / \mathrm{ha}$ available $\mathrm{P}_{2} \mathrm{O}_{5}$ and 322.94 $\mathrm{kg} /$ ha available $\mathrm{K}_{2} \mathrm{O}$. The experiment was conducted in a Randomized Block Design replicated three times with thirteen treatments comprising cultural and chemical weed control methods with weed free and weedy check treatments.

The number of weeds present in one square meter area and dry weight of weeds in each plot was counted and measured at 30,60 DAS and at harvest. The weeds were uprooted from the destructive sampling area of one $\mathrm{m}^{2}$ and were oven dried to a constant weight at $60^{\circ} \mathrm{C}$ and the dry weight of weeds was expressed in $\mathrm{g}$ per $\mathrm{m}^{2}$. Weed control efficiency at harvest and weed index after harvest of different treatments were computed based on the formula suggest by Gautam et al. (1975) and Gill and Vijaykumar in (1969). Data on grain yield was recorded after harvest.

\section{Weed control efficiency (\%):}

Weed control efficiency was calculated by the help of formula:

$\mathrm{WCE}=(\mathrm{X}-\mathrm{Y} / \mathrm{X}) * 100$

where, $\mathrm{X}$ : Weed dry matter production in weedy plot.

Y: Weed dry matter production in treated plot.

\section{Weed index (\%):}

Weed index indicates the extent of reduction in yield due to weed competition. It was worked out for different treatments by adopting the formula:

\section{Weed index $=(A-B / A) * 100$}

where, A: seed yield of the best treatment,

B: seed yield of the particular treatment for which the index is computed.

\section{Morphological parameters:}

Height was measured from the base of the stem to the tip of main shoot. The average was calculated and expressed as height $(\mathrm{cm})$ per plant. For dry matter study plant samples were initially air dried for 2-3 days. After partial air drying samples were oven dried at $65^{\circ} \mathrm{C}$ till constant weight was obtained. Then, weight was expressed as dry matter (g) per plant. Progressive number of functional leaves i.e. fully developed and green leaves (trifoliate) were recorded on each plant. The average was calculated and expressed as functional leaves per plant. Plant was taken out carefully with the help of fork. The roots were then washed with water and the functional root nodules were counted. The mean number of nodules was measured. The leaf area (sq. $\mathrm{cm}$.) was estimated by using the automatic laser area meter and then values were later converted to square decimeter.

\section{Leaf area index:}

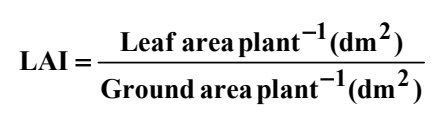

\section{RESULTS AND DISCUSSION}

The results obtained from the present investigation as well as relevant discussion have been summarized under following heads :

\section{Effect on weed indices :}

Weed population and weed dry weight:

Different weed management practices significantly reduced the weed population and dry matter of weeds. Minimum weed population and weed dry matter was observed under pre-emergence application of pendimethalin@1.5 kg/ha(15.75 and 2.01) followed by pendimethalin $1.0 \mathrm{~kg} / \mathrm{ha}(19.25$ and 3.05$)$ among 
herbicidal treatments. Among cultural practices two hand weeding at 15 and 30 days after sowing (27.40 and 3.78) recorded minimum weed population and weed dry matter than rest of the treatments as compared to the weedy check treatment.

The pre-emergence application of pendimethalin was found more effective and superior in controlling the broad spectrum of annual grassy and broad leaved weeds, also gave significantly lower weed population and weed dry weight as compared to imazethapyr and postemergence application of quizalofop-p-ethly and fenoxyprop-p-ethly. Similar observations were recorded by Mishra and Bhanu (2006) (Table 1).

\section{Weed control efficiency:}

Weed free condition recorded higher weed control efficiency (97.06) among all the weed control treatments throughout the crop growth stages. In case of chemical weed control treatments among all the weed control treatments at all the crop growth stages, result of pendimethalin as pre-emergence application gave better WCE. Similar results were reported by Ahmed et al. (2008) in peanut crop. Pre-emergence application of pendimethalin@1.5kg/ha (87.42) recorded higher weed control efficiency followed by pendimethalin@1 kg/ha (80.91) and fenoxyprop-p-ethyl at $125 \mathrm{gha}^{-1} \mathrm{POE}$ (80.29) in black gram as compared to weedy check (Malliswari et al., 2008).

\section{Weed index :}

Weed index was computed as the yield reduction comparative to the highest yielding treatment (weed free). Among the weed management practices pre-emergence application of Pendimethalin @ $1.5 \mathrm{~kg} / \mathrm{ha}$ recorded minimum weed index $(20.46 \%)$. Better weed control in this treatments provided favourable condition for crop growth and less yield reduction than other treatments. Weedy check treatment recorded the maximum weed index $(59.13 \%)$ among all the treatments. Rao and Rao (2003) also reported weed index of $49 \%$ due to uncontrolled weed growth during the crop season.

\section{Effect on plant morphological parameters :}

Plant height:

Significant reduction in plant height at all crop growth stages was noticed in weedy check plot. This might be due to keen competition between crop and weeds for growth resources. Among the rest of the weed control treatments pre-emergence application of pendimethalin@1.5 kg/ha (17.7 and 44.37) recorded significantly higher plant height closely followed by cultural practices of two hand weeding at 15 and 30 days

\begin{tabular}{|c|c|c|c|c|}
\hline Treatments & $\begin{array}{c}\text { Total weed population }\left(\mathrm{m}^{-2}\right) \\
\text { at harvest }\end{array}$ & $\begin{array}{l}\text { Weed dry weight } \\
\left(\mathrm{g} / \mathrm{m}^{2}\right) \\
\text { at harvest }\end{array}$ & $\begin{array}{l}\text { Weed control } \\
\text { efficiency }(\%) \\
\text { at harvest }\end{array}$ & $\begin{array}{c}\text { Weed index } \\
(\%) \text { after } \\
\text { harvest }\end{array}$ \\
\hline $\mathrm{T}_{1}-$ Weed free & 2.39 & 0.47 & 97.06 & 0 \\
\hline $\mathrm{T}_{2}-$ Weedy check & 65.44 & 15.98 & - & 59.13 \\
\hline $\mathrm{T}_{3}-2$ Hand weeding (15 and 30 DAS) & 27.40 & 3.78 & 76.35 & 26.77 \\
\hline $\mathrm{T}_{4}-2$ Hoeing (10 and 20 DAS) & 44.00 & 5.99 & 62.52 & 45.82 \\
\hline $\mathrm{T}_{5}$ - Imazethapyr at $50 \mathrm{~g} / \mathrm{ha} \mathrm{PE}$ (At sowing) & 38.62 & 5.00 & 68.71 & 52.18 \\
\hline $\mathrm{T}_{6}$ - Imazethapyr at $75 \mathrm{~g} /$ ha PE (At sowing) & 33.10 & 3.95 & 75.28 & 33.43 \\
\hline $\mathrm{T}_{7}$ - Pendimethalin at $1000 \mathrm{~g} /$ ha PE (At sowing) & 19.25 & 3.05 & 80.91 & 21.52 \\
\hline $\mathrm{T}_{8}$ - Pendimethalin at $1500 \mathrm{~g} /$ ha PE (At sowing) & 15.75 & 2.01 & 87.42 & 20.46 \\
\hline $\mathrm{T}_{9-}$ Fenoxyprop-p-ethyl at $100 \mathrm{~g} /$ ha POE (15 DAS) & 30.70 & 3.88 & 75.72 & 29.33 \\
\hline $\mathrm{T}_{10}$ - Fenoxyprop-p-ethyl at $125 \mathrm{~g} /$ ha POE (15 DAS) & 20.60 & 3.15 & 80.29 & 22.49 \\
\hline $\mathrm{T}_{11}$ - Quizalofop-p- ethyl at $50 \mathrm{~g} /$ ha POE (15 DAS) & 50.20 & 10.02 & 37.30 & 36.57 \\
\hline $\mathrm{T}_{12}$ - Quizalofop-p- ethyl at $75 \mathrm{~g} /$ ha POE (15 DAS) & 35.55 & 4.95 & 69.02 & 31.54 \\
\hline $\begin{array}{l}\mathrm{T}_{13} \text { - Imazethapyr at } 50 \mathrm{~g} \text { / ha PE fb Quizalofop-p- ethyl } \\
\text { at } 50 \mathrm{~g} \text { / ha POE (At sowing fb } 15 \text { DAS) }\end{array}$ & 47.00 & 8.80 & 44.93 & 34.11 \\
\hline S.E.土 & 2.31 & 0.45 & - & - \\
\hline C.D.at $5 \%$ - & 6.75 & 1.32 & - & - \\
\hline G.M. - & 33.08 & 5.46 & 65.81 & 31.8 \\
\hline
\end{tabular}


after sowing and pendimethalin @ $1.0 \mathrm{~kg} / \mathrm{ha}$ as preemergence application (17.47and 43.43). (Table 2).

Increased plant height in pendimethalin at both concentration as a pre-emergence application and cultural practices of two hand weedings might be due to least weed population recorded in this treatments which reduced the crop weed competition leading to more plant height. Imazethapyr at both concentrations recorded comparatively lower plant height than pendimethalin and this collaborated the findings of Rao and Rao (2003) who reported stunted growth of black gram due to imazethapyr.

Number of functional leaves plant ${ }^{-1}$ :

Increased number of functional leaves was observed in all the weed control treatments compared to weedy check. In rest of the treatments, pre-emergence application of pendimethalin@1.5 kg/ha recorded significantly maximum number of functional leaves (4.8, and 12.37) which was closely followed by pendimethalin (a) $1.0 \mathrm{~kg} / \mathrm{ha} \mathrm{PE}$ at 15 and 30 DAS and two hand weeding at 30 and 60 DAS (Table 2). This may be attributed to vigorous plant growth due to better weed control in these treatments. By 60 DAS stage functional leaves were marginally reduced due to initiation of leaf senescence.

\section{Leaf area plant ${ }^{-1}$ :}

Among all the weed control treatments, weed free treatment recorded significantly highest leaf area per plant and weedy check treatment recorded lowest leaf

\begin{tabular}{|c|c|c|c|c|c|c|c|c|c|c|c|c|}
\hline \multirow{2}{*}{ Treatments } & \multicolumn{2}{|c|}{$\begin{array}{l}\text { Plant height } \\
\text { (cm) }\end{array}$} & \multicolumn{2}{|c|}{$\begin{array}{l}\text { Functional } \\
\text { leaves plant }{ }^{-1}\end{array}$} & \multicolumn{2}{|c|}{$\begin{array}{l}\text { Leaf area plant } \\
\left(\mathrm{cm}^{2}\right)\end{array}$} & \multicolumn{2}{|c|}{$\begin{array}{c}\text { Leaf area } \\
\text { index }\left(\mathrm{dm}^{2}\right)\end{array}$} & \multicolumn{2}{|c|}{$\begin{array}{c}\text { Dry matter } \\
\text { weight plant }^{-1}(\mathrm{~g})\end{array}$} & \multicolumn{2}{|c|}{$\begin{array}{l}\text { Root nodules } \\
\text { plant }^{-1}\end{array}$} \\
\hline & $\begin{array}{c}30 \\
\text { DAS }\end{array}$ & $\begin{array}{c}60 \\
\text { DAS } \\
\end{array}$ & $\begin{array}{c}30 \\
\text { DAS }\end{array}$ & $\begin{array}{c}60 \\
\text { DAS }\end{array}$ & $\begin{array}{c}30 \\
\text { DAS }\end{array}$ & $\begin{array}{c}60 \\
\text { DAS }\end{array}$ & $\begin{array}{c}30 \\
\text { DAS }\end{array}$ & $\begin{array}{c}60 \\
\text { DAS }\end{array}$ & $\begin{array}{c}30 \\
\text { DAS }\end{array}$ & $\begin{array}{c}60 \\
\text { DAS } \\
\end{array}$ & $\begin{array}{c}30 \\
\text { DAS } \\
\end{array}$ & $\begin{array}{c}60 \\
\text { DAS }\end{array}$ \\
\hline $\mathrm{T}_{1}-$ Weed free & 20.47 & 49.33 & 4.9 & 13.67 & 420 & 888.4 & 1.4 & 2.96 & 1.68 & 19.17 & 21.33 & 32 \\
\hline $\mathrm{T}_{2}-$ Weedy check & 16.03 & 37.8 & 3.07 & 6.87 & 326 & 557.8 & 1.09 & 1.86 & 0.68 & 12.03 & 7.67 & 12.67 \\
\hline $\mathrm{T}_{3}-2$ Hand weeding ( $15 \mathrm{fb} 30$ & 18.13 & 43.33 & 4.47 & 12.3 & 415 & 815.3 & 1.38 & 2.72 & 1.26 & 17.77 & 14.67 & 24.67 \\
\hline DAS) & & & & & & & & & & & & \\
\hline $\mathrm{T}_{4}-2$ Hoeing (10 fb $\left.20 \mathrm{DAS}\right)$ & 16.37 & 40.2 & 3.6 & 9.07 & 345 & 643.6 & 1.15 & 2.15 & 0.7 & 15.77 & 10 & 13.33 \\
\hline $\begin{array}{l}\mathrm{T}_{5} \text { - Imazethapyr @ } 50 \mathrm{~g} \mathrm{ha}^{-1} \mathrm{PE} \\
\text { (At sowing) }\end{array}$ & 15.17 & 39.5 & 3.07 & 7.2 & 330 & 585.5 & 1.1 & 1.95 & 0.93 & 15.77 & 8.67 & 18 \\
\hline $\begin{array}{l}\mathrm{T}_{6} \text { - Imazethapyr @ } 75 \mathrm{~g} \mathrm{ha}^{-1} \mathrm{PE} \\
\text { (At sowing) }\end{array}$ & 17.07 & 42.23 & 3.6 & 10 & 335 & 719.1 & 1.12 & 2.4 & 1.05 & 16 & 11 & 19 \\
\hline $\begin{array}{l}\mathrm{T}_{7} \text { - Pendimethalin @1000 } \mathrm{gha}^{-1} \\
\text { PE (At sowing) }\end{array}$ & 17.47 & 43.43 & 4.7 & 10.9 & 414 & 795.1 & 1.38 & 2.65 & 1.25 & 17.95 & 14 & 25 \\
\hline $\begin{array}{l}\mathrm{T}_{8} \text { - Pendimethalin @1500 } \mathrm{gha}^{-1} \\
\text { PE (At sowing) }\end{array}$ & 17.7 & 44.37 & 4.8 & 12.37 & 418 & 886.7 & 1.39 & 2.96 & 1.36 & 18.77 & 18 & 27 \\
\hline $\begin{array}{l}\text { T9 - Fenoxyprop-p-ethyl @100g } \\
\text { ha }^{-1} \text { POE (15 DAS) }\end{array}$ & 16.47 & 42.77 & 3.47 & 9.13 & 384 & 667.4 & 1.28 & 2.22 & 0.91 & 16.33 & 11.33 & 21 \\
\hline $\begin{array}{l}\text { T10 - Fenoxyprop-p-ethyl @ } 125 \text { g } \\
\text { ha }^{-1} \text { POE (15 DAS) }\end{array}$ & 17.27 & 43.13 & 4.4 & 10.8 & 411 & 779.6 & 1.37 & 2.6 & 1.12 & 17 & 14.33 & 22.33 \\
\hline $\begin{array}{l}\mathrm{T}_{11} \text { - Quizalofop-p-ethyl @ } 50 \mathrm{~g} \mathrm{ha}^{-} \\
{ }^{1} \text { POE (15 DAS) }\end{array}$ & 15.57 & 40.3 & 3.33 & 7 & 331 & 573.2 & 1.1 & 1.91 & 0.75 & 15.07 & 8.33 & 19.33 \\
\hline $\begin{array}{l}\text { T } 12 \text { - Quizalofop-p-ethyl @ } 75 \text { g } \\
\text { ha-1 POE (15 DAS) }\end{array}$ & 16.7 & 42.7 & 3.67 & 8.33 & 335 & 658.1 & 1.12 & 2.19 & 1.01 & 16.27 & 11 & 20.33 \\
\hline $\begin{array}{l}\mathrm{T}_{13} \text { - Imazethapyr@ } 50 \mathrm{~g} \mathrm{ha}^{-1} \mathrm{PE} \\
\text { and Quizalofop-p-ethyl @ } 50 \mathrm{~g} \mathrm{ha}^{-1}\end{array}$ & 15.57 & 40.63 & 3.67 & 8.9 & 332 & 608.3 & 1.11 & 2.03 & 0.7 & 15.47 & 9.67 & 18 \\
\hline POE (At sowing and15 DAS) & & & & & & & & & & & & \\
\hline $\mathrm{SE}(\mathrm{m}) \pm$ & 0.62 & 1.36 & 0.39 & 0.29 & 15.74 & 34.66 & - & - & 0.09 & 0.8 & 0.65 & 1.51 \\
\hline C.D. at $5 \%$ & 1.82 & 3.96 & 1.14 & 0.86 & 45.94 & 101.2 & - & - & 0.27 & 2.35 & 1.91 & 4.42 \\
\hline G.M. & 16.92 & 42.29 & 3.9 & 9.41 & 368.9 & 706 & 1.23 & 2.35 & 1.03 & 16.46 & 12.31 & 21.22 \\
\hline
\end{tabular}


Impact of integrated weed management practices on weed and morphological parameters of black gram

area throughout crop growth stages. In rest of the weed control treatments, pre-emergence application of pendimethalin@1.5 kg/ha recorded significantly maximum leaf area plant $^{-1}$ (418 and 886) which was closely followed by two hand weeding at 15 and 30 days after sowing (415 and 815) at 30 and 60 days after sowing. This is due to the consequence of more number of functional leaves coupled with increased leaf expansion because of reduced weed competition and competitive edge in crops.

\section{Leaf area index:}

Among all the weed control treatments, highest leaf area index $\left(1.40\right.$ and $\left.2.96 \mathrm{dm}^{2}\right)$ was observed with weed free condition and weedy check treatment recorded lowest leaf area ( 1.09 and $1.86 \mathrm{dm}^{2}$ ) throughout the crop growth period. In rest of the weed control treatments, pre-emergence application of pendimethalin @ $1.5 \mathrm{~kg} /$ ha recorded maximum leaf area index and superior over the rest of the weed control treatments throughout the crop growth stages.

\section{Total dry matter weight per plant :}

Among all the weed control treatments, weed free treatment recorded significantly highest and weedy check treatment recorded significantly lowest dry matter accumulation throughout the crop growth period. In rest of the weed control treatments, pre-emergence application of pendimethalin@ @ $1.5 \mathrm{~kg} /$ ha significantly recorded maximum dry matter accumulation per plant which was closely followed by pendimethalin@1.0 kg/ ha PE and by two hand weeding at 15 and 30 DAS at 30 days after sowing. This was mainly because of weed competition across the crop growth period with better control of early and later emerging weeds consequently benefiting crop growth in terms of more height, functional leaves and leaf area. Crop weed competition during the entire season caused least dry matter accumulation per plant under weedy check. This conforms with the findings of Ramamoorthy and Lakshmanachary (2001) and Ramamoorty et al. (2003). Raman et al. (2005) also reported that weed control treatments significantly increased the growth and its components which was attributed to reduced weed competition for nutrients, light and space.

\section{Number of root nodule:}

Among all the weed control treatments, number of root nodules was significantly recorded maximum in weed free treatment and minimum in weedy check treatment throughout the crop growth period. In rest of the weed control treatments, pre-emergence application of pendimethalin@1.5 kg/ha recorded significantly highest number of root nodules per plant (10 and 27) and superior over the rest of the weed control treatments throughout the crop growth period. In general no definite trend was observed with respect to root nodules plant.

\section{Conclusion:}

Different chemicals and cultural weed control treatments improved morphological parameters significantly. It can be stated that the better and higher morphological improvement over control was observed in treatment with pre-emergence application of pendimethalin@1.5 kg/ha except weed free treatment over weedy check and superior as well as economical and feasible over all other treatments.

\section{REFERENCES}

Ahmed, Y. M., Mustafa, A. S., Reda, L. A., Khozimy, A. M. and Mosteh, Y. Y. (2008). Efficiency of the selected herbicides in controlling weeds and their side effects on peanut. J. Plant Protection Res., 48(3) : 355-363.

Ali, M., Pandey, R.K. and Rawat, C.R. (1982). Studies on intercropping and weed management in piqeonpea under dryland conditions. Madras. J. Agric. Sci., 69 :474-478.

Gautam, K. C., Mani, V. S. and Sharma, R. K. (1975). A note on efficiency, Selectivity and residual toxicity of some soil applied pesticide in black gram. Indian J. Weed Sci., 7(1): 72-74.

Gill, H. S. and Kumar, Vijay (1969). Weed index a new method for reporting with control trial. Indian J. Agron., 14(1): 96-98.

Kasar, B. A., Chavan, K. R.,Nemade, S. U., More, G. B. and Apotikar, Varsha (2009). Efficacy of different herbicides for weed control in groundnut in combination with cultural methods of weed control. Crop Res., 37(1,2\&3) : 46-48.

Malliswari, T., Reddy, M.P., Sagar, K.G. and Chandrika, V. (2008). Effect of irrigation on weed management practices on weed control and yield of blackgram. Indian J. Weed Sci., 40(1\&2) : 85-86.

Mishra, J. S. and Bhanu, C. (2006). Effect of herbicides on weeds, nodulation and growth of rhizobium in summer blackgram. Indian J. Weed Sci.,38(1\&2) : 150153. 
J. P. Bholane, Kavita D. Rajput and V.M. Bhale

Ramamoorthy, D. and Laxamanachary, A. S. (2001). Ecological studies of herbicides on the total biomass of the black gram crop. Advances in Plant Sci., 14(1): 115-122.

Ramamoorthy, D., Laxamanachary, A.S. and Sundaramoorthy, P. (2003). Impact of weed competition on the total biomass of black gram. Advances in Plant Sci., 16 (1): 223-228.

Raman, R., Kappuswamy, G. and Krishnamoorthy, R. (2005). Response of weed management practices on the growth and yield of Urdbean. Legume Res.,28(2): 122124.

Rao, A. S. and Rao, R. S. N. (2003). Bioefficacy of clodinafop- propargyl on Echinochloa spp. In black gram. Indian J. Weed Sci., 35 (3/4): 251-252.

Sharma, J. and Nayital, S.C. 1991. Crop-weed competition in maize+black gram intercropping system. Indian $J$. Agronomy. 36: 64-67.

Vats, O. P. and J. S. Sawhney. 1981. Crop weed competition studies in black gram. Abstract of papers, Annual Conference of Indian Society of Weed Science, India. 8.

Yadav, S. K., S. P. Singh and V. M. Bhan. 1983. Weed control in chickpea. Tropical Pest Management. 29 (3) : 297398.

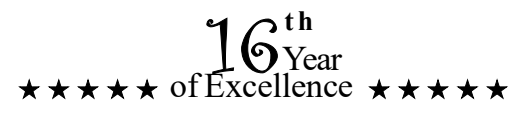

